\title{
Conidial fungi from the semi-arid Caatinga Biome of Brazil. A new species of Dictyochaeta
}

\author{
Silva SS ${ }^{1}$ and Gusmão LFP ${ }^{1}$
}

${ }^{1}$ Universidade Estadual de Feira de Santana, Departamento de Ciências Biológicas, Laboratório de Micologia, AvenidaTransnordestina, s/n, Novo Horizonte, 44036-900, Feira de Santana, BA, Brazil. silvanasdasilva@hotmail.com

Silva SS, Gusmão LFP 2013 - Conidial fungi from the semi-arid Caatinga Biome of Brazil. A new species of Dictyochaeta. Mycosphere 4(4), 701-705, Doi 10.5943/mycosphere/4/4/6

\begin{abstract}
During a survey of freshwater conidial fungi associated with submerged plant debris, an interesting specimen of Dictyochaeta was found. Dictyochaeta aciculata sp. nov. is characterized by 3 -septate, acicular conidia with rounded bases. These morphological characteristics differentiate the species found in Brazil from previously described taxa in Dictyochaeta and it is, therefore, described and illustrated herein as a novel species.
\end{abstract}

Key words - freshwater fungi - lotic environment - taxonomy - tropical

\section{Introduction}

The genus Dictyochaeta Speg. was erected in 1923, with the type species D. fuegiana and it was characterized by setae, conidiogenous cells which are mono- or polyphialidic and conidia 0septate, without setulae. A brief historical review on nomenclatural aspects on Dictyochaeta and related genera, such as Codinaea Maire, Codinaeopsis Morgan-Jones and Dictyochaetopsis Aramb. \& Cabello, was present by Li et al. (2012). The same authors, recognized molecular data from Reblová (2000) and Reblová \& Winka (2000) for phylogeny of the teleomorph Chaetosphaeria Tul. \& C. Tul. and its anamorphs.

Molecular studies conducted by Reblová \& Winka (2000) revealed that setulate and asetulate conidia of Dictyochaeta species grouped into distinct sub groups in the phylogenetic tree. Thus, Reblová (2000) suggested maintaining the genus name Dictyochaeta for species without setulae and Codinaea for species with setulae.

Despite these taxonomic suggestions, many authors (Whitton et al. 2000, Kirschner \& Chen 2002, Cruz et al. 2008) do not agree with Reblová (2000). In contrast, more recent workers are already following (Seephueak et al. 2010, Seifert et al. 2011, Li et al. 2012). Seifert et al. (2011) accepted the results of molecular data, however, they do not separate the two genera based on presence and absence of setulae. For this paper we follow Reblová $(2000,2004)$ and Reblová \& Winka (2000).

Dictyochaeta species occur decomposing plant material in terrestrial (Kuthubutheen \& Nawawi 1991a, Hernández-Gutiérrez \& Mena Portales 1996, Cruz et al. 2008) and aquatic (Kuthubutheen \& Nawawi 1991a,b,c, Cai et al. 2004) habitats. In Brazil, 17 species have been found associated with litter (Cruz et al. 2008, Santa Izabel et al. 2011) and two new species have been described (Cruz et al. 2008). In this paper, through investigations of conidial fungi 
associated with submerged plant debris in rivers and streams in different areas in the Caatinga Biome, we found an interesting specimen, whose morphological characters agree with those of Dictyochaeta, but it differs from all previously described species in the genus. We therefore propose the Brazilian specimen as a new species.

\section{Materials \& Methods}

Samples of submerged plant debris (leaves, petioles, twigs and bark) were collected in rivers and streams of the five priority areas for biodiversity conservation included in the semi-arid Caatinga Biome, northeast of Brazil (Velloso et al. 2002). Field expeditions were conducted in 2011 and 2012, into four states: Paraiba State- Brejo Paraibano, Ceará State- Chapada do Araripe and Serra de Ibiapaba, Piauí State- Serra das Confusões and Bahia State- Serra da Jibóia.

The material was transported in plastic bags to the laboratory, washed in water and incubated in moist chambers at $25^{\circ} \mathrm{C}$ for 30 days. During this period the samples were examined for the presence of conidial fungi. Slides containing the reproductive structures of fungi were made with resin PVL (polyvinyl alcohol + lactic acid + phenol) and deposited in the Herbarium of the State University of Feira de Santana (HUEFS).

\section{Results}

Dictyochaeta aciculata S.S. Silva \& Gusmão, sp. nov.

Figs $1-5$ Mycobank MB804878

Etymology - aciculata, referring to the conidial morphology.

Colony effuse, brown. Mycelium, partly superficial, partly immersed in substatrum. Setae sterile, straight to slightly flexuous, up to11-septate, light brown, finely verrucose, 195-205 × 6-9 $\mu \mathrm{m}$. Conidiophores macronematous, mononematous, simple, solitary or in groups of 2-3 associated with base of setae, smooth, straight to slightly flexuous, 3-5-septate, pale brown to subhyaline at apex, 46.5-70 $\times 4.5 \mu \mathrm{m}$. Conidiogenous cells monophialidic, terminal, integrated, conspicuous collarete, smooth, pale brown to subhyaline, 24-31.5 $\times 4.5 \mu \mathrm{m}$. Conidia acicular with rounded bases, 3-septate, smooth, hyaline, 36-40 × 1.5-2 $\mu \mathrm{m}$; arranged in slimy mass.

Teleomorph - unknown.

Geographical distribution - Piauí State, Brazil.

Holotypus - BRAZIL: Piauí: Caracol, Serra das Confusões, on submerged petiole, 6.V.2011; S.S.Silva (HUEFS 192225).

\section{Discussion}

Among the species of Dictyochaeta, falcate and lunate conidia are the most common and most representatives. However, only a few species produce septate, non-setulate conidia. These are D. fruticola (M.S. Patil, U.S. Yadav \& S.D. Patil) Whitton, McKenzie \& K.D. Hyde, D. guadalcanalensis (Matsush.) Kuthub \& Nawawi, D. ixorae (M.S. Patil, U.S. Yadav \& S.D. Patil) Whitton, McKenzie \& K.D. Hyde, D. lunata (Matsush.) Whitton, McKenzie \& K.D. Hyde and D. setosa (S. Hughes \& W.B. Kendr.) Whitton, McKenzie \& K.D. Hyde, which are morphologically most similar to D.aciculata (Table 1).

Despite morphological similarities, D. aciculata differs from all other species in the genus by having 3 -septate, acicular conidia. In addition the setae are finely verrucose which is another morphological character that distinguishes it from all previously described species in Dictyochaeta. 


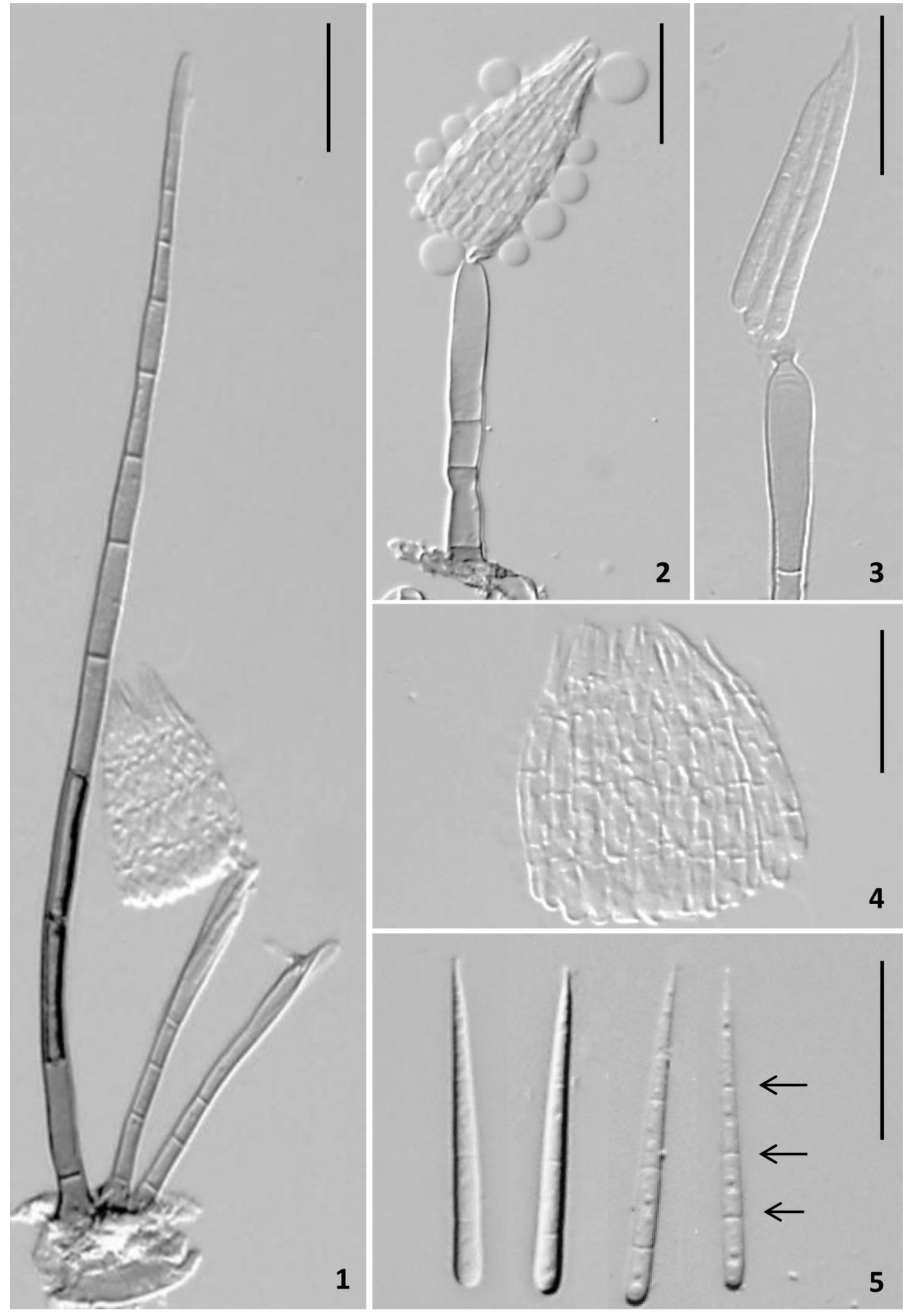

Figs 1-5 - Dictyochaeta aciculata. 1 General aspect. 2 Conidiophore. 3 Detail of conidiogenous cell. 4 Conidia in a slime mass. 5 Conidia. Arrows indicate the septa. Bars: $20 \mu \mathrm{m}$. 
Table 1 Comparison of Dictyochaeta species morphologically similar to D. aciculata (data from original descriptions).

\begin{tabular}{|c|c|c|c|c|c|c|}
\hline \multirow[t]{2}{*}{ Species } & \multirow[t]{2}{*}{ Setae } & \multirow[t]{2}{*}{ Conidiogenesis } & \multicolumn{3}{|c|}{ Conidia } & \multirow[t]{2}{*}{ References } \\
\hline & & & $\overline{\text { Size }(\mu \mathrm{m})}$ & Form & $\overline{\text { Septa }}$ & \\
\hline D. aciculata & present & monophialidic & $36-40 \times 1,5-2$ & acicular & 3 & Present study \\
\hline D. fruticola & present & monophialidic & $36-40 \times 1.8$ & cylindric & 1 & Whitton et al. (2000) \\
\hline D. guadalcanalensis & absent & polyphialidic & $\begin{array}{l}18-27 x \\
4.5-5.5\end{array}$ & obclavate & 1 & $\begin{array}{l}\text { Kuthubutheen } \\
\text { Nawawi (1991c) }\end{array}$ \\
\hline D. ixorae & absent & monophialidic & $18-12 \times 1.8$ & falcate & 1 & Whitton et al. (2000) \\
\hline D. lunata & absent & $\begin{array}{l}\text { monophialidic/ } \\
\text { polyphialidic }\end{array}$ & $\begin{array}{l}10-16 \times \\
2.5-3.5\end{array}$ & lunate & 1 & Whitton et al. (2000) \\
\hline D. setosa & present & monophialidic & $20-24 \times 2-2.8$ & falcate & 1 & Whitton et al. (2000) \\
\hline
\end{tabular}

\section{Acknowledgements}

The authors thank the Program of Research on Biodiversity in the Brazilian semi-arid (PPBIO semi-arid/ Ministry of Technology and Science) and Programa de Pós-Graduação em Botânica (PPGBot/ UEFS). SS Silva and LFP Gusmão extend their gratitude to CNPq for financial support (Proc. 474589/2008-0).

\section{References}

Cai L, Zhang K, McKenzie EHC, Hyde KD. 2004 - Linocarpon bambusicola sp. nov. and Dictyochaeta curvispora sp. nov. from bamboo submerged in freshwater. Nova Hedwigia 78(3-4), 439-445.

Cruz ACR, Leão-Ferreira SM, Barbosa FR, Gusmão LFP. 2008 - Conidial fungi from semi-arid Caatinga biome of Brazil. New and interesting Dictyochaeta species. Mycotaxon 106, 15-27.

Hernández-Gutiérrez A, Mena Portales J. 1996 - Dictyochaeta minutissima sp. nov. on Coccothrinax miraguama from Cuba. Mycological Research 100(6), 687-688.

Kirschner R, Chen CJ. 2002 - Dictyochaeta multifimbriata, a new species from Taiwan. Mycological Progress 1(3), 287-289.

Kuthubutheen AJ, Nawawi A. 1991a - Eight new species of Dictyochaeta (hyphomycetes) from Malaysia. Mycological Research 95(10): 1211-1219.

Kuthubutheen AJ, Nawawi A. 1991b - Dictyochaeta macrospora sp. nov.: a litter-inhabiting hyphomycete from Malaysia. Mycological Research 95, 248-250.

Kuthubutheen AJ, Nawawi A. 1991c -Dictyochaeta guadalcanalensis comb. nov. and several new records of the genus in Malaysia. Mycological Research 95(10), 1220-1223.

Li De-Wei, Kendrick B, Chen J. 2012 - Two new hyphomycetes: Codinaea sinensis sp. nov. and Parapleurotheciopsis quercicola sp. nov., and two new records from Quercus phillyraeoides leaf litter. Mycological Progress 11, 899-905.

Reblová M. 2000 - The genus Chaetosphaeria and its anamorphs. Studies in Mycology 45, 149168.

Reblová M. 2004 - Four new species of Chaetosphaeria from New Zealand and redescription of Dictyochaeta fuegiana. Studies in Mycology 50, 171-186.

Reblová M, Winka K. 2000 - Phylogeny of Chaetosphaeria and its anamorphs based on morphological and molecular data. Mycologia 92(5), 939-954.

Santa Izabel TS, Santos DS, Almeida DAC, Gusmão LFP. 2011 - Fungos conidiais do bioma Caatinga II. Novos registros para o continente americano, Neotrópico, América do Sul e Brasil. Rodriguésia 62(2), 229-240.

Seephueak P, Petcharat V, Phongpaichit S. 2010 - Fungi associated with leaf litter of para rubber (Hevea brasiliensis). Mycology 1(4), 213-227. 
Seifert K, Morgan-Jones G, Gams W, Kendrick B. 2011 - The Genera of Hyphomycetes. CBS Biodiversity Series no. 9. Utrecht. CBS-KNAW Fungal Biodiversity Centre.

Velloso AL, Sampaio EVSB, Pareyn FGC. (Eds). 2002-Ecorregiões: Propostas para o bioma Caatinga. Resultados do Seminário de Planejamen to Ecorregional da Caatinga/Aldeia-PE. Recife: Associação Plantas do Nordeste; Instituto de Conservação Ambiental The Nature Conservancy do Brasil. $76 \mathrm{p}$.

Whitton SR, McKenzie EHC, Hyde KD. 2000 -Dictyochaeta and Dictyochaetopsis species from the Pandanaceae. Fungal Diversity 4, 133-158. 